\title{
Oily Sludge Recovery using Microwave Pyrolysis Technique
}

\author{
KHAMAEL M. ABUALNAJA ${ }^{1}$, HALA M. ABO-DIEF ${ }^{2 *}$, OLA A. ABU ALI', \\ ABDULLAH AL-ANAZI ${ }^{4}$ and ASHRAF T. MOHAMED ${ }^{3}$
}
1,2,3,4 Department of Chemistry, Al-Taif Faculty of Science, Al-Taif University, Al-Taif, Kingdom of Saudi Arabia.
${ }^{1}$ On leave from the Egyptian Petroleum Research Institute, Nasr City, Cairo, Egypt.
${ }^{3}$ Design and Production Department, Faculty of Engineering, Minia University, Minia, Egypt.
${ }^{*}$ Corresponding author E-mail: Mohamed.hala91@yahoo.com

http://dx.doi.org/10.13005/ojc/370104

(Received: November 09, 2020; Accepted: February 20, 2021)

\begin{abstract}
The oily sludge treatments catch widespread attention. But, management of sludge is difficult and costly undertaking. The oil recovery pyrolysis temperature, heating rate and carbon wt.\% is discussed. The recovered aliphatic, aromatic, elemental components and gases were obtained with respect to the nitrogen flow rate. The present work showed that as the heating rate increases, both the $\%$ pyrolysis oil and gases increases up to $600^{\circ} \mathrm{C}$, while the $\%$ pyrolysis char decreases. Beyond $600^{\circ} \mathrm{C}$ the pyrolysis gases $\%$ increases, the pyrolysis oil \% decreases while the \% pyrolysis char continuous decreases. Gas chromatography, and calorific value used to examine the hydrocarbon compositions of the virgin, sludge, and pyrolysis oils.
\end{abstract}

Keywords: Virgin, Sludge and pyrolysis oils, Oil recovery temperature, Heating rate and carbon wt.\%, Oil recovery and gas chromatography, microwave, calorific value.

\section{INTRODUCTION}

The fossil fuels largest consumption with the energy challenge, environmental sustainability, and cleaner energy requirements attracted interest in recent years ${ }^{1-2}$. Bilo'o, and Benoît ${ }^{3}$ stated that alternate sources such as renewable energy are required. The goal of many countries to increase their economies income is crude oil, despite the outcome that has towards the environment. Oil wastes making dangerous risk for human health and natural ${ }^{4-5}$. Oily sludge generated during the production, transportation, storage and in the oil refinery plants ${ }^{6-7}$. Abo-Dief et al., ${ }^{8}$ produced biodiesel from five fresh vegetable oils. Roozbehani ${ }^{9}$ discussed the potentials and the related issues of combusting crude oil sludge to obtain the best concentration with three main factors, including $\mathrm{pH}$, bio-surfactant concentration and salinity. Through adding manure, Liu et al., ${ }^{10}$ and Kumar and Mohan ${ }^{11}$ conducted bioremediation of oily sludge. Gozan ${ }^{12}$ showed that the sludge oil range from benzene, phenols to polycyclic aromatic hydrocarbons, but Hu et al., ${ }^{13}$ stated that little attention paid to handle crude oil. Islam ${ }^{14}$ found that the sludge containing recoverable oil less than $40 \%$. Chen et al., ${ }^{15}$ examined the sewage sludge pyrolysis process for pyrolytic oil.

This is an Open Access article licensed under a Creative Commons license: Attribution 4.0 International (CC- BY). Published by Oriental Scientific Publishing Company @ 2018

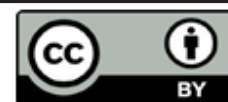


Abualnaja and Abo-Dief ${ }^{1}$ recovered $90 \%$ of oily sludge using ultrasonic method. Almasi et al., ${ }^{16}$ discussed the main effects of ultrasonic sludge. Mwamlima ${ }^{[17}$ concluded that the slowpyrolysis reactor was relatively simple to operate for trained staff. Rogers and Brammer ${ }^{18}$ designed a model takes account sales of pyrolysis bio-char. Barry et al., ${ }^{19}$ defined that pyrolysis is viable as a thermally self sufficient process to transform sewage sludge into biochar. Orabi et al., ${ }^{20}$ discussed the $\mathrm{N}_{2}$ flow rate effects on the pyrolysis products of the used oil. Abo-Dief et al., ${ }^{21}$ used the microwave energy to pyrolysis the automotive engine oil using the microwave energy. The present work aiming at recovering sludge oil using the pyrolysis technique at various pyrolysis temperature, heating rate and carbon wt.\%. The recovered aliphatic, aromatic, elemental components and gases obtained at various values of nitrogen flow rates. Also, the variation of the microwave pyrolysis energy and the pyrolysis gases calorific values with microwave pyrolysis temperature detected.

\section{EXPERIMENTAL}

During the periodical cleaning at an oil refinery in the Egyptian east cost of the red sea, the sludge collected from the tanks bottom. The sludge heated to $100^{\circ} \mathrm{C}$ for $12 \mathrm{~h}$ to remove moisture and cooled to room temperature $\left(16^{\circ} \mathrm{C}\right)$. Microwave oil pyrolysis device shown in Fig. 1. The sludge elemental contents; $\mathrm{C}, \mathrm{H}, \mathrm{N}, \mathrm{S}$, and $\mathrm{O}$ detected. The total ion content percentage (TIC\%) measured. The calorific value of the pyrolysis gases calculated.

$25 \mathrm{~g}$ feedstock with nitrogen gas flow rate ranging from 50 to $1000 \mathrm{~mL} / \mathrm{min}$ used. Samples heated to temperatures of; $400,500,600,700$ and $800^{\circ} \mathrm{C}$ at a heating rate ranging from $10^{\circ} \mathrm{C} /$ min to $25^{\circ} \mathrm{C} / \mathrm{min}$ for carbon/sludge wt. $\%$ ranging from $25 \%$ to $100 \%$. The pyrolysis oil collected and weighed. The specific gravity, the higher heating value and water content used to specify the pyrolysis oil properties. The hydrocarbon composition and calorific value of the pyrolysis oil determined and compared with that of both virgin and sludge oils.

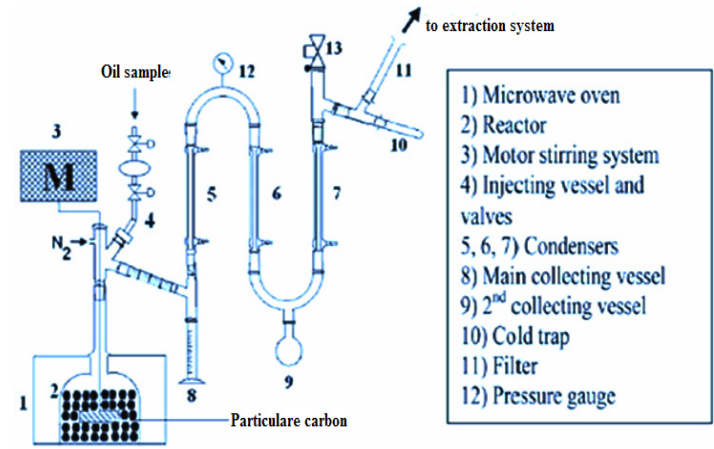

Fig. 1. Microwave pyrolysis device ${ }^{21}$ RESULTS AND DISCUSSIONS

\section{Effect of Temperature}

Figure 2 illustrated the temperature effect on the \% pyrolysis oil, gas and char with various values of heating rates at $0 \% \mathrm{CC}$ and $25 \% \mathrm{CC}$. As the test temperature increases, the pyrolysis oil \% increases up to $600^{\circ} \mathrm{C}$ followed by rapid decrement, the $\%$ pyrolysis gases increases gradually up to $600^{\circ} \mathrm{C}$ followed by rapid increment and the pyrolysis char continually due to the sludge oil vaporization in agreement with ${ }^{21}$. The higher amounts of gaseous products related to the hydrocarbons cracking into smaller molecules in agreement with Lam et al.,22.

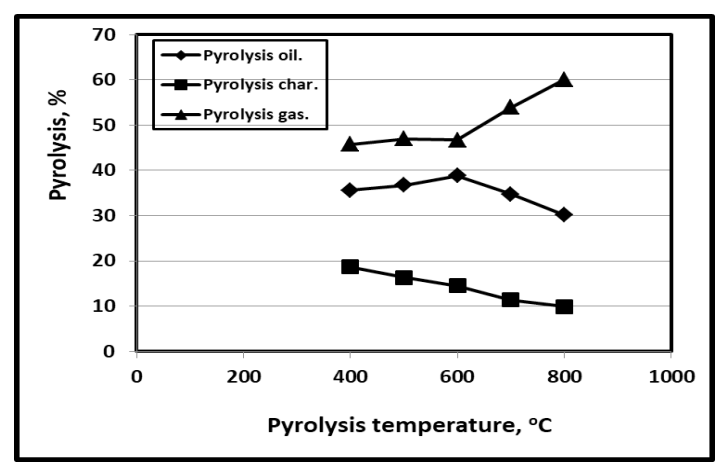

(2.a) $0 \%$ CC \& $10^{\circ} \mathrm{C} /$ minute

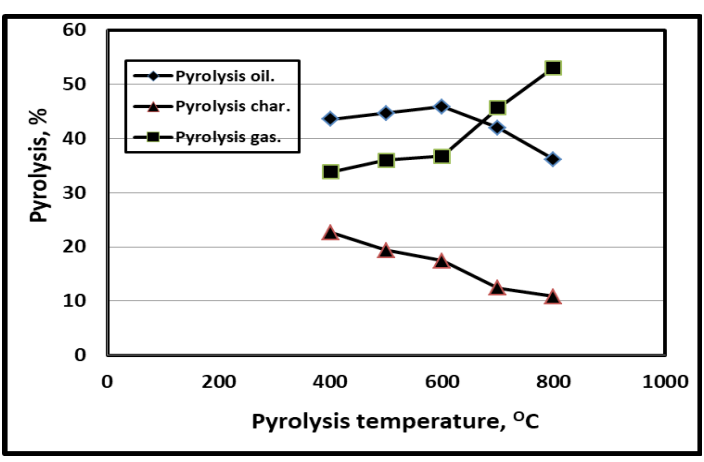

(2.b) $25 \%$ CC \& $10^{\circ} \mathrm{C} /$ minute 


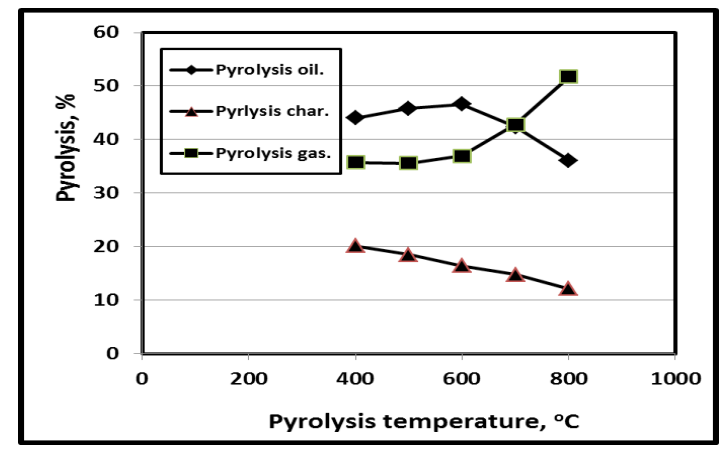

(2.c) $25 \% \mathrm{CC} \& 15^{\circ} \mathrm{C} /$ minute

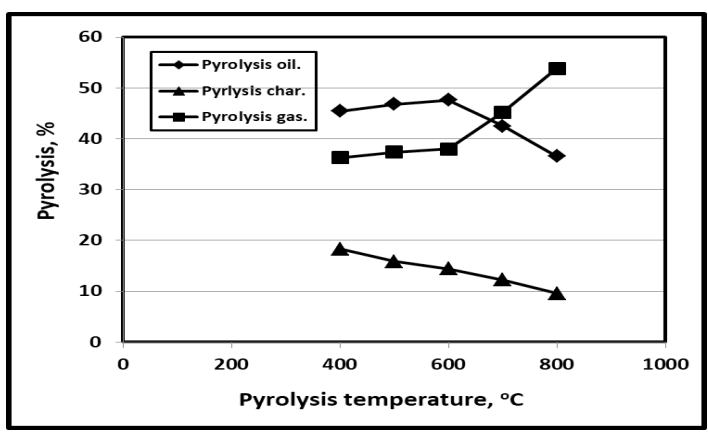

(2.d)25\% CC \& 200C/minute

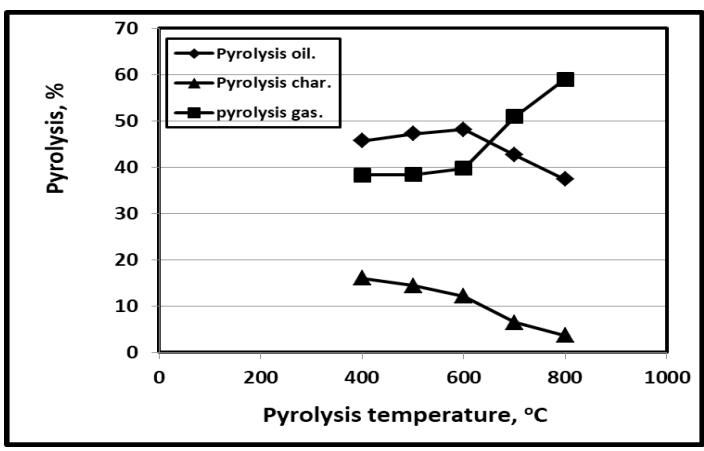

(2.e) $25 \%$ CC \& $250 \mathrm{C} /$ minute

Fig. 2. Effect of heating rate on pyrolysis products wt.\% at $25 \mathrm{wt} . \%$ carbon at various temperatures

Effect of Carbon Content wt.\% (CC)

Figure 3 illustrated the variation of \% pyrolysis oil, gas and char with various values of wt. \% of carbon content (\%CC) at different test temperature values and $25^{\circ} \mathrm{C} / \mathrm{min}$ heating rate. It is found that, the values of \%pyrolysis oil are; 43.53, $48.17,49.17,50.17$ and $53.8 \%$, the values of $\%$ pyrolysis gases are; $43.19 \%, 39.76 \%, 36.72,40.76$, and 38.13 . The values of pyrolysis char are; $13.28 \%$, $12.07,10.07,09.07$ and 8.07 at $0 \%, 25 \%, 50 \%, 75 \%$ and $100 \%$ carbon wt. $\%$ respectively and $600^{\circ} \mathrm{C}$. So, as the carbon wt. \% increases, the \% pyrolysis oil increases up to $600^{\circ} \mathrm{C}$ over $600^{\circ} \mathrm{C}$, the $\%$ pyrolysis oil decreases continuously due to the cracking of the sludge oil hydrocarbons. The char values continually decreases with carbon wt.\% increment ${ }^{22}$. The oily sludge total petroleum hydrocarbon (TPH) contents values are within the previous investigators in agreement with Mohan and Chandrasekhar ${ }^{23}$.

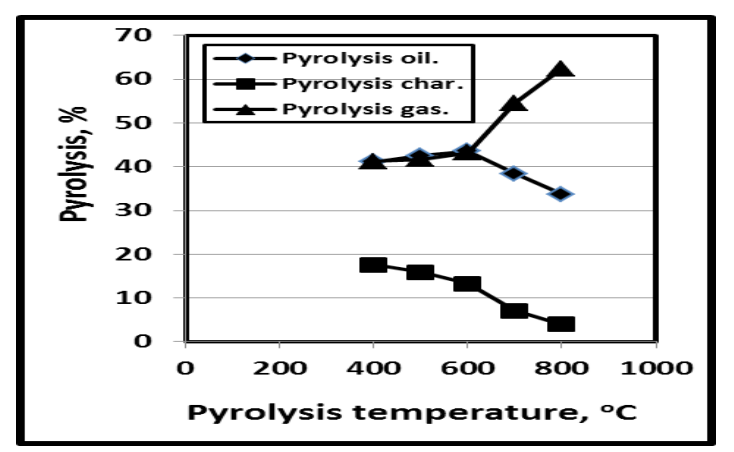

(3.a) $25^{\circ} \mathrm{C} / \mathrm{min} \& 0$ wt. $\%$ CC

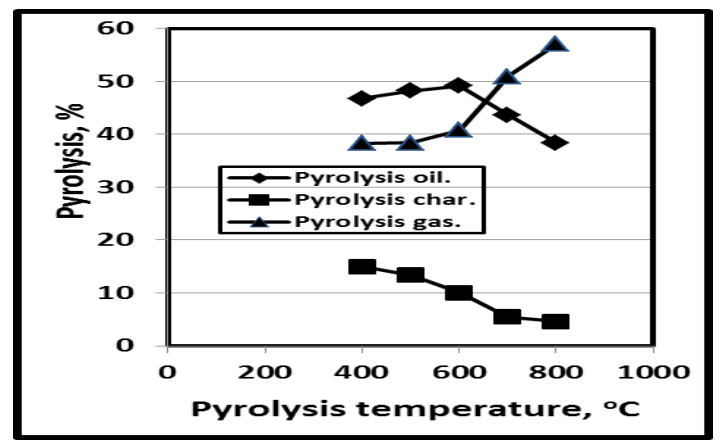

(3.b) $25^{\circ} \mathrm{C} / \mathrm{min} \& 10 \mathrm{wt} . \% \mathrm{CC}$

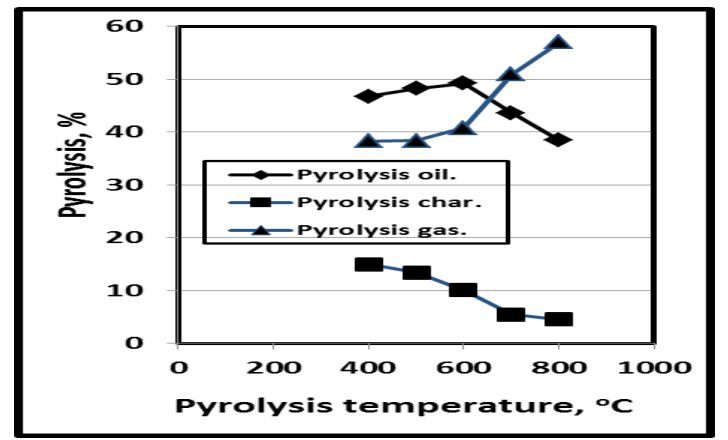

(3.c) $25^{\circ} \mathrm{C} / \mathrm{min} \& 15 \mathrm{wt} . \% \mathrm{CC}$

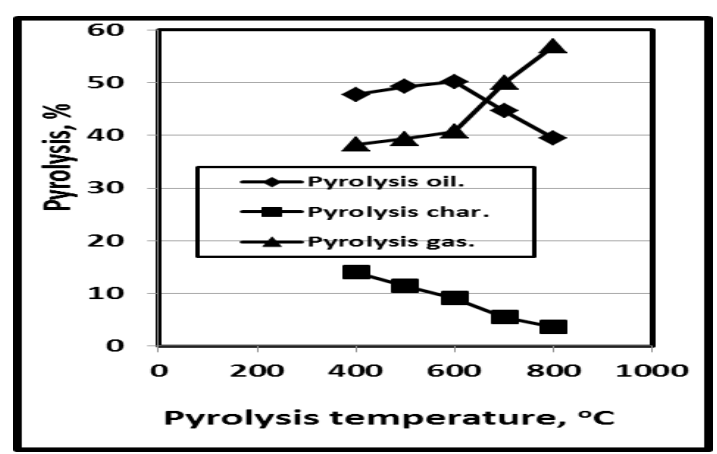

(3.d) $25^{\circ} \mathrm{C} / \mathrm{min} \& 20 \mathrm{wt} . \% \mathrm{CC}$ 


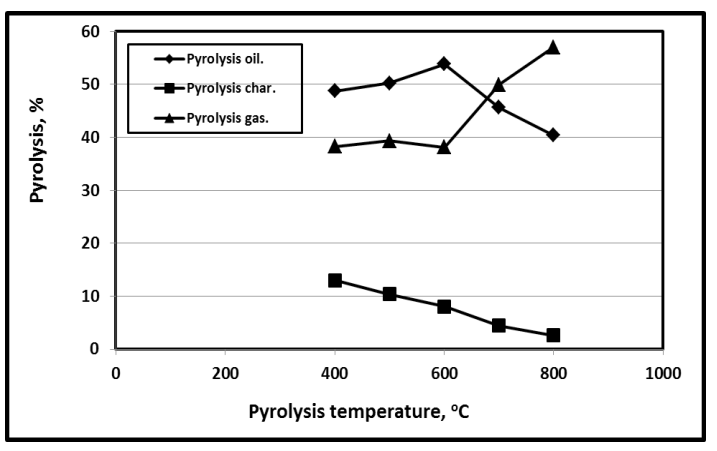

(3.e) $25^{\circ} \mathrm{C} / \mathrm{min} \& 25$ wt. $\%$ CC.

Fig. 3. Effect of carbon wt. $\%$ on pyrolysis products wt.\% at $25^{\circ} \mathrm{C} / \mathrm{min} \mathrm{HR}$ and various temperatures

\section{Effect of Nitrogen}

Figure 4 illustrated the $\mathrm{N}_{2}$ effect on the aliphatic. Up to $50 \mathrm{~mL} / \mathrm{min} \mathrm{N}_{2}$, the aliphatic components increase. Between 50 and $800 \mathrm{~mL} /$ $\min \mathrm{N}_{2}$, the alkanes increases rapidly, the alkenes increases slightly and the naphthenic decreases. Over $800 \mathrm{~mL} / \mathrm{min} \mathrm{N}_{2}$, the alkanes increases slightly, the alkenes without any change in pause and the naphthenic continually decreases, in agreement with ${ }^{22}$ Fig. 5 illustrated the variation of light aromatics \%wt.; benzene, toluene, xylene and alkyl-benzenes that found in the pyrolysis oils at various values of $\mathrm{N}_{2}$ flow rates. Up to $50 \mathrm{~mL} / \mathrm{min}_{2}$ flow rate, all the light aromatics wt\% increases, toluene has higher increment value followed by benzene, alkylbenzenes and xylene respectively. With $\mathrm{N}_{2}$ flow rate increment up to $1000 \mathrm{~mL} / \mathrm{min}$ the alkyl-benzenes increases while toluene decreases followed by both benzene and xylene respectively.

Figures 6 to 10 showed a comparison between pyrolysis, fresh and sludge oils constituents wt.\% with $\mathrm{N}_{2}$ flow rates. Fig. 6 showed that the pyrolysis oil has the higher carbon wt.\% compared to both fresh and sludge oils due to the carbon added to the reactor. With $\mathrm{N}_{2}$ flow rated increment, the pyrolysis oil carbon wt.\% decreases since the pyrolysis process heating medium provides chemical reduction of both carbon and oxygen while both fresh and sludge oils have constant values of carbon. Fresh oil carbon wt.\% is higher than that of sludge oil since the ignition process that used carbon is not carried yet. Fig. 7 showed that with $\mathrm{N}_{2}$ flow rates increment, sludge oil has higher constant hydrogen wt.\% due to the dehydrogenation and aromatization processes occurred in agreement with Guri et al., ${ }^{4}$. Fig. 8 illustrated that the pyrolysis oils has a lower oxygen wt.\% compared to both fresh and sludge oils due to the use of oxygen in carbon bed heating that required in the pyrolysis operation and decarboxylation occurring during thermal treatment processes in agreement with ${ }^{7}$. Fig. 9 showed that the pyrolysis oil has a higher $\mathrm{N}_{2}$ wt.\% due to the extra $\mathrm{N}_{2}$ purge gas. The lower sludge oil $\mathrm{N}_{2}$ wt. $\%$ related to that consumed in the production of gases and char ${ }^{19}$. Fig. 10 illustrated that pyrolysis oil has a lower sulphur wt.\% compared to the both sludge and fresh oils due to the sulphur oxides that generated during the pyrolysis process in agreement with Lima et al., ${ }^{6}$.

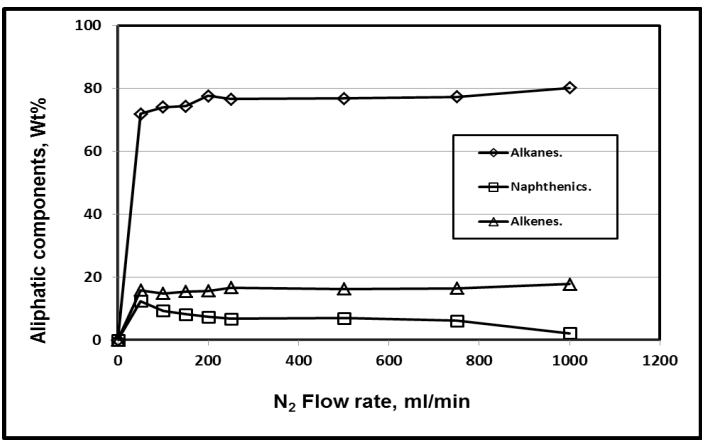

Fig. 4. Variation of aliphatic with $\mathrm{N}_{2}$ flow rates

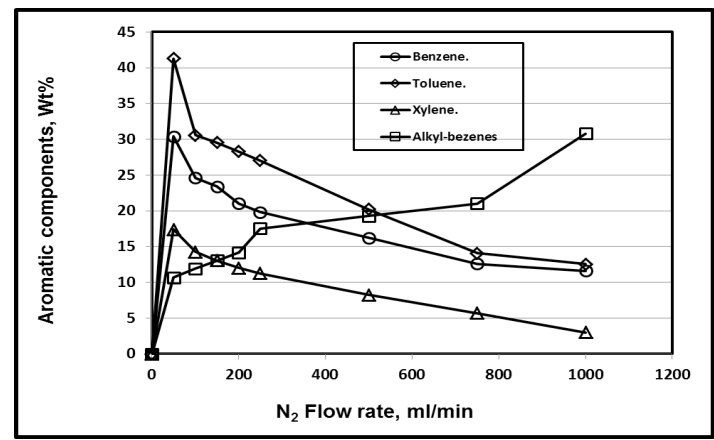

Fig. 5. Variation of aromatic wt\% and the $\mathrm{N}_{2}$ flow rates

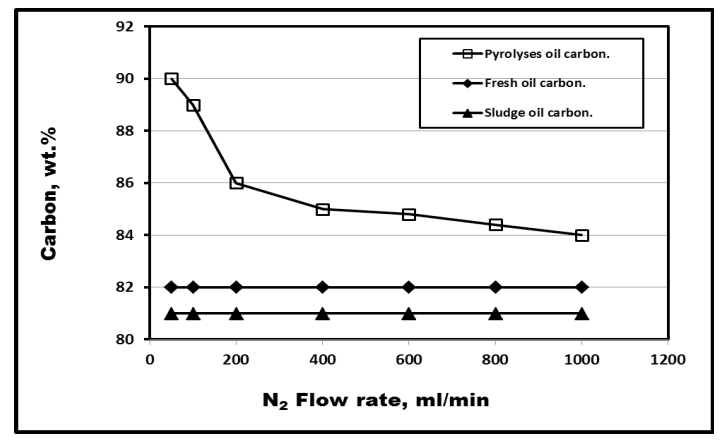

Fig. 6. Variation of carbon wt.\% with with $\mathrm{N}_{2}$ Flow rate 


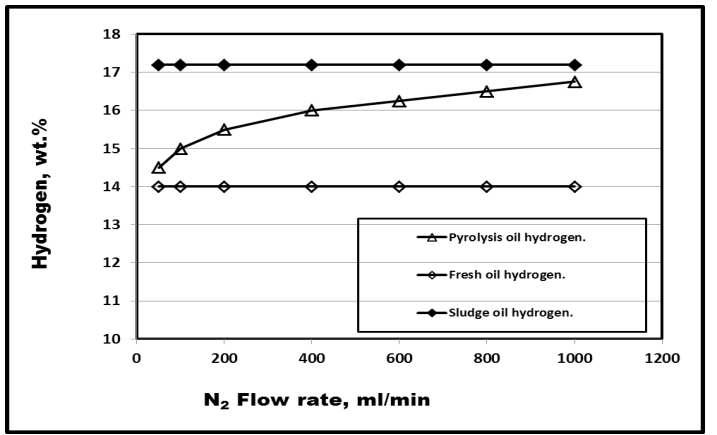

Fig. 7. Variation of hydrogen wt.\% with with $\mathrm{N}_{2}$ Flow rate

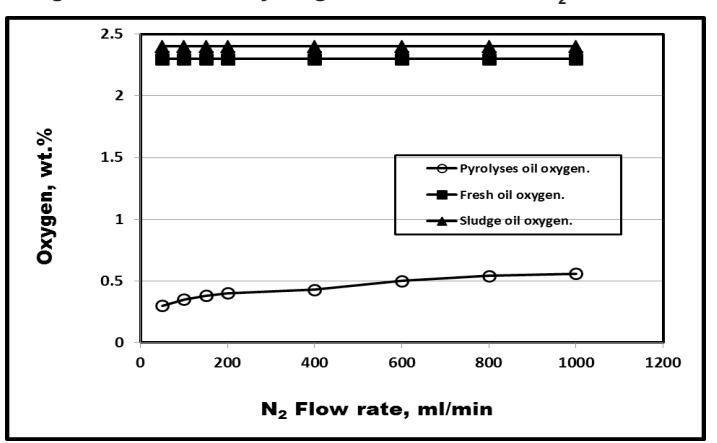

Fig. 8. Variation of oxygen wt.\% with $\mathrm{N}_{2}$ Flow rate

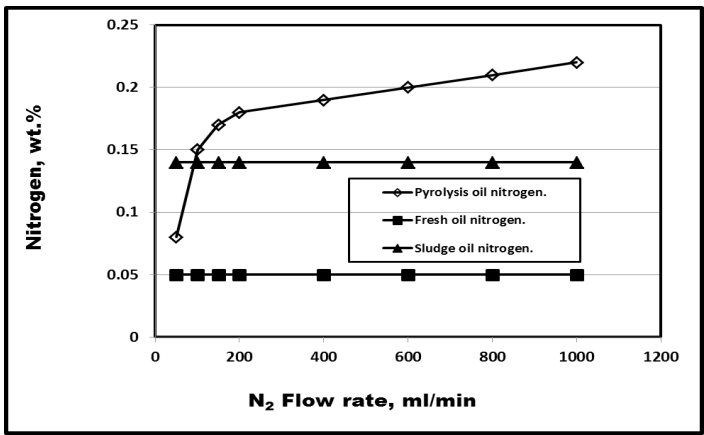

Fig. 9. Variation of nitrogen wt.\% with N2 Flow rate

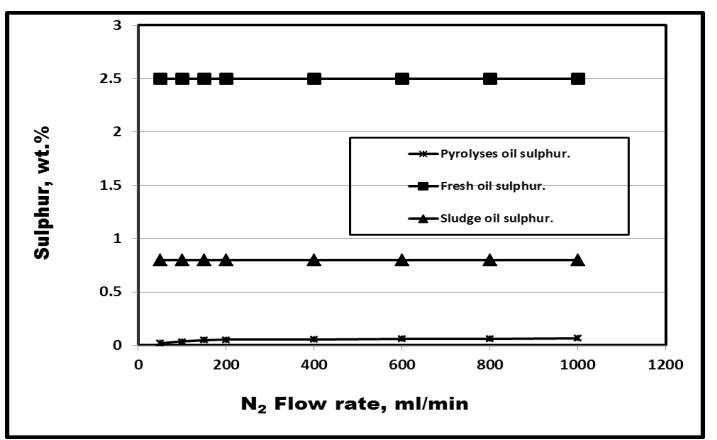

Fig. 10. Variation of sulphur wt.\% with $\mathrm{N}_{2}$ flow rate

Figure 11 showed the relation between the microwave pyrolysis energy and temperature for pyrolysis liquids, gases and solids. It is clear that up to $200^{\circ} \mathrm{C}$ all the constituents energies increases, while from $200^{\circ} \mathrm{C}$ to $600^{\circ} \mathrm{C}$, both liquids and gases energies increases with an optimum liquids value but the solid energy decreases. After $600^{\circ} \mathrm{C}$, the gases energy increases rapidly due to the temperature effect that generated pyrolysis volatiles while both liquids and solids energies decreases in agreement with Lam et al.,22.

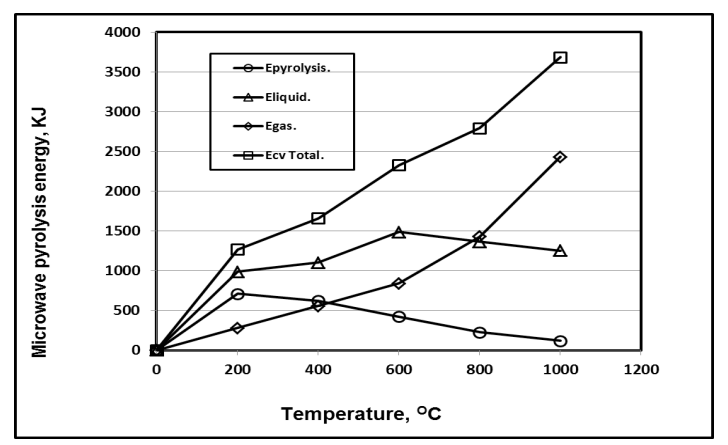

Fig. 11.Variation of microwave energy recovery with temperature

\section{Calorific Value}

Figure 12 showed that with temperature increment, there is a sharp increases of propene followed by ethene and methane repectivele and a stepless increment of propane and ethane. Both butanes and butenes calorific values decreases with temperature increment in agreement with ${ }^{4}$.

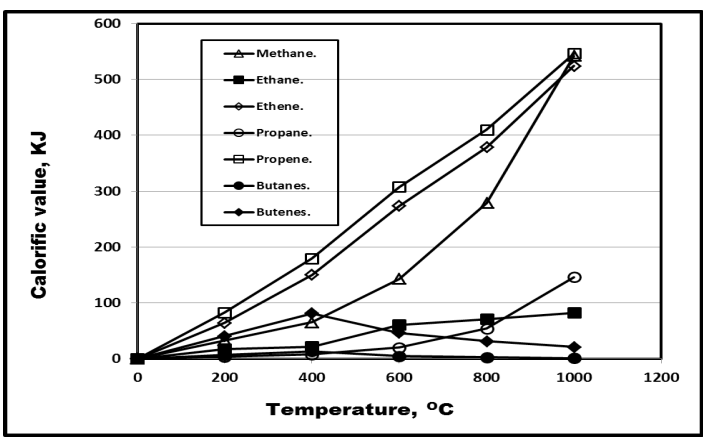

Fig. 12. Calorific value of pyrolysed gases CONCLUSION

1. Sludge recovered successfully and generated valuable products.

2. As the heating rate increases, both the $\%$ pyrolysis oil and gases increases up to $600^{\circ} \mathrm{C}$, while the \%pyrolysis char decreases. Beyond $600^{\circ} \mathrm{C}$, the pyrolysis gases $\%$ increases, the pyrolysis oil\% decreases and the \% pyrolysis char continuous decreases.

3. With the increment of $\mathrm{N}_{2}$ flow rate, the pyrolysis oil nitrogen, hydrogen and oxygen 
increases, while both fresh and sludge oils have no change values.

4. As $\mathrm{N}_{2}$ flow rates increases, the pyrolysis oil carbon wt.\% decreases with non-change values of sulphur wt.\%, while there is no change of both carbon wt. $\%$ and sulphur wt.\% value occurred for both fresh and sludge oils with $\mathrm{N}_{2}$ flow rates.

5. The pyrolysis oil contained higher carbon and nitrogen contents with lower oxygen, hydrogen and sulphur contents compared to both fresh and sludge oils.

6. $600^{\circ} \mathrm{C}$ is the ideal temperature for recovering pyrolysis sludge oil.

\section{ACKNOWLEDGMENT}

This research did not receive any specific grant from funding agencies in the public, commercial, or not-for-profit sectors.

\section{Conflicts of Interest}

The authors declare no conflict of interest.

\section{REFERENCES}

1. Abualnaja, K.; Abo-Dief, H. Asian Journal of Chemistry., 2018, 30, 2641-2646.

2. Hanif, M.; Capareda, S.; lqbal, H.; Arazo, R.; Baig, M. Plosone., 2016, 1-11.

3. Bilo'o, Z.; Benoît, N. International Journal of Environ. Sciences., 2013, 3(5), 1373- 1382.

4. Guri, A.; Guri, S.; Lubonja, O. Academic Journal of Interdisciplinary Studies MCSER., 2013, 2, 626-634.

5. Jadoon, S.; Malik, A.; Amind, A. Chemistry and Materials Research., 2017, 9, 5-12.

6. Lima, C.; Lima, R.; Fabiula, E.; Silva, B.; Kelly, K.; Filho, O.; Soares, S.; Araújoc, A. Rev. Virtual Quim., 2014, 6, 1160-1171.

7. Islam, B.; Int. J. Chem. Sci., 2015, 13, 1584-1602.

8. Abo-Dief, H.; Emam, A.; Abualnaja, K.; Mohamed, A. Orient. J. Chem.(OJC)., 2018, 34, 1011-1015.

9. Roozbehani, B.; Saadat, A.; Jaafarzadeh, N. American Journal of Oil and Chemical Technologies., 2013, 1, 10-16.

10. Liu, W.; Luo, Y.; Teng, Y.; Li, Z.; Ma, L. Environ Geochem Health., 2010, 32, 23-29.

11. Kumar, B.; Mohan, R. International Journal of Engineering Research \& Technology (IJERT)., 2013, 2, 359-370.

12. Gozan, M. Energy and Environment Research., 2014, 4, 22-28.
13. Hu, G.; Li, J.; Zeng, G. Journal of Hazardous Materials., 2013, 261, 470-490.

14. Islam, B. Int. J. Chem. Sci., 2015, 13, 15841602.

15. Chen, G.; Li, J.; Lin, H.; Wu F.; Chao, Y. Energies., 2018, 11, 1-17.

16. Almasi, A.; Mosavi, A.; Mohammadi, M.; Azemnia, S.; Godini, K.; Zarei, A.; Mohammadi, S.; Saleh, E. Global NEST Journal., 2016, 18, 771-777.

17. Mwamlima, P. Report, University of Dar es Salaam, College of Engineering and Technology (CoET)., 2017.

18. Rogers, J.; Brammer, J. Biomass and Bioenergy., 2012, 36, 208-217.

19. Barry, D.; Briens, C.; Berruti, F. Engineering Conferences International, The University of Western Ontario., 2017.

20. Orabi, R.; Abo-Dief, H.; Mohamed, A. International Journal of Emerging Trends in Engineering and Development., 2015, 3, 91-101.

21. Abo-Dief, H.; Altalhi, A.; and Mohamed, A. J. of Industrial and Intelligent Information., 2014, 4, 314-319.

22. Lam, S.; Russell, A.; Chase, A. Ind. Eng. Chem. Res., 2010, 49, 10845-10851.

23. Mohan, S.; Chandrasekhar K. Bioresouce Technology., 2011, 102, 9532-9541, 2011. 